\title{
Demographic Security Trends in Southeastern Europe
}

\author{
Dario Malnar, Ana Malnar
}

\section{Abstract}

Over the past three decades we have witnessed an evolution of the concept of security in general and of demographic security as a specific field of security studies. The approach to security has been changing both in regards to a widening of subjects and referent objects of security, and a widening of the security domain. Consideration of the demographic component in the security sphere has evolved in accordance with this development; the scope of perspectives through which demographic security is viewed and defined has expanded - the population composition, population dynamics and human capital paradigm. Aspects of demographics and security are in continuous interaction and interdependence which significantly determines demographic security and national security.

The aim of this paper is to establish a specific link between demographic security and security in ten post-socialist countries of South Eastern Europe (SEE). In accordance with this aim, an analysis has been made of the compositional elements and population dynamics in order to determine demographic security of the observed states. The analysis indicates unfavourable demographic security, and negative demographic composition and dynamics in most of observed states, which suggests that demographic security will have a continuing negative impact on the security of the countries analysed and the region as a whole.

\section{KEY WORDS:}

demography, security, South Eastern Europe 
Population is, along with territory and sovereign authority, the constituent element of the state as a permanent and organised community.' Population is the foundation of all territorial, regional, economic, social and other sorts of planning, a fundamental territorial resource and potential and is - in every country - of national strategic interest (Šterc and Komušanac 2011: 693).

The study of population - demos ${ }^{2}$ - and changes related to the population is therefore a permanent activity of the institutions that shape social, cultural, political, economic, as well as security, segments of the social and state system.

In public, the problem of the population was for a long time confined to real and potential numbers of the population, its implications on comparative development and the power of certain countries and, at the global level to the implications on general conditions of development and survival of people on our planet. In contrast, in the last fifty years, attention has been drawn to the problems of dynamic and structural interdependence and patterns of demographic development, whereby demographic factors are not autonomous, but they, along with economic, technological, social, political and environmental factors, make up a set of conditions, causes and consequences of a unique social development process (Wertheimer-Baletić 1999: xiii).

The development of security studies is also characterised by the widening of the context in which security is observed, starting with the expansion of the thematic area to areas through which security is defined. Of particular importance is the contribution from members of the Copenhagen School whose work has established a foothold for the consideration of security in a widened and deepened context as compared to the previous period

1 More on the issue of the constituent elements of the state in the Convention on the Rights and Duties of States (Montevideo Convention)

2 The population of a state is a community of people which consists of the citizens of the state and of foreigners who have continuously inhabited the territory of that state (Degan 2000: 228). 
focusing on state security through military power and demographic trends.

"Demographic phenomena per se are seldom the cause of conflict ... demographic factors are therefore to be viewed as one set of many factors potentially contributing to armed conflict, interacting with others in complex series of linkages" (Nichiporuk 2000: xi). Demographic changes more often incite internal crises, and even conflicts that subsequently have the potential for wider destabilisation - refugee waves, using opposing sides to conduct a proxy war, and similar. At the same time, demographic features and trends have without a doubt had an impact on the geopolitical picture and relationships in a certain area.

The end of the Cold War prompted a consideration of security which changed the prevailing concept of focusing on the state and military power. As the work of the Copenhagen School broadened the definition of security, security studies began to deal with the factors that also emerged in the demographic studies discussed by Wertheimer-Baletić, and the notion of security was widened to include political, economic, military, societal and environmental security. It was clear that "the nature of the future international security environment will be determined by complex interactions between geopolitical alignments, technological advances, economic developments, demographic factors, and environmental trends" (Nichiporuk 2000: 1).

It is without doubt that modern security studies view demographic development as a determinant security factors and that demographic factors may represent an indication of the security situation and possible changes.

The aim of this paper is to determine the correlation between demographic security and aspects of security as defined by the Copenhagen School, and subsequently to define the demographic security of ten SEE states. These are countries that in the late 1980s and early 1990s of the 20th century entered the transition process from single-party and directed economy socialist/communist regimes to a democratic and free market system. ${ }^{3}$

3 Albania, Bosnia and Herzegovina, Bulgaria, Croatia, Kosovo, Macedonia, Montenegro, Romania, Serbia and Slovenia. 


\section{Security and population}

The traditional concept of security, based on a realistic approach as defined by Morghentau (1967) and his followers, was focused on protection of the territorial integrity of the state and its defence against the attack of another state. ${ }^{4}$ The object of security is the state itself and the concept is primarily based on the security of the state. ${ }^{5}$ The security effect of the population was seen principally as a function of how an aggregate population size affected the power potential of a given nation state. Nichiporuk calls this intellectual approach "static" and emphasises that it "saw population size and density as being one independent variable in an aggregate "bucket of capabilities" that determined a country's level of power and influence in international system" (Nichiporuk 2000: 5).

The traditional concept of security prevailed during the Cold War both in democratic and totalitarian states, however, even though totalitarian states at the time, with regard to the concept of international security, based their approach to security on a realistic concept and their approach to population on a static concept, they also saw the population in another, intrastate context.

In totalitarian states there is no clear definition of national security. Those matters are mistaken for the security of the ruling elite or ideal state as the organisation superior to the nation (Podolski 1999: 46). It is in this context, in the intrastate sphere, that the population is also viewed, and is segmented along ideological, ethnic, and social lines. The homogeneity and potential of a group, separately or in correlation with other groups, for provoking intrastate ethnic or ideologically motivated conflicts, as a threat to the regime's security, is assessed. The demographic structure and processes influencing the creation of hyper nations and ideological patterns are also analysed. This approach widened the context in which impact of demographic factors on state power and security was observed, and therefore the components and content of demographic security as well. The approach was dynamic in character.

4 This approach reflects the definition of national security as was given by Luciani that "National security can be defined as the ability to resist external aggression" (Luciani 1989: 151). 
In the wider international context the dynamic approach was developed and strengthened during the 1980s and 1990s. Nichiporuk states that "this dynamic paradigm emphasizes not population size as a component of national power calculations but rather the interactions between population pressures and environmental degradation, mass migrations, resource depletion, forced refugee flows, ethnic conflict, hypernationalism, and urbanization [...]" (Nichiporuk 2000: 6).

The development of elements of the dynamic paradigm, as it is called by Nichiporuk, coincides with tendencies in the development of a modern concept of security developed after the concept of security had been affected by the fundamental changes in the security environment after the Cold War. One could even say that there has been a shift from the state as a central subject of security to people as groups and individuals. This shift in security studies was initiated by Barry Buzan and then further developed in his work and the work of theorists associated with the Copenhagen School. ${ }^{6}$ Buzan expanded the understanding of the concept of security by widening it into five fields: military, economic, environmental, political and societal security. "Referent objects can be the state (military security); national sovereignty, or an ideology (political security); national economies (economic security); collective identities (societal security); species or habitats (environmental security) " (Buzan et al. 1998). The perception of security has become more subjective and individualised. The modern concept of security views population trends through their impact on a country's potential to meet the needs of the population and ensure the protection of common and individual rights. As Grizold (1998: 32) states, it is about "...activities which ensure fulfilment of societies basic functions (socio-economic, socio-political, psycho-social, cultural, ecological and other)".

In the modern concept of security the psychological dimension-what make us feel secure or insecure - has gained priority over the physical, and stems directly from the population and its structure, particularly from personal values. A strengthening of the psychological dimensions of security is compatible with demographic development, which marks the second demographic transition (SDT). According to the original SDT

6 It is primarily about the Barry Buzan's book "People, states and fear" 1983, following the research and studies of Buzan, Ole Weaver and Jaap de Wilde.. 
concept, large scale changes in family and reproductive behaviour are the consequence of cultural and ideational changes (e.g. a shift towards secular individualism and an orientation towards personal self-fulfilment) driven primarily by economic affluence (Van de Kaa 1987).

So demographic security "...is not only to assess the direct impact of demographic trends on population numbers, economic size, and defense capabilities, but also to consider how these trends may indirectly affect capabilities by altering economic performance, social temperament, and national goals." (Jackson and Howe 2008: 1)

Herd and Sargsyan, in their study of Russian demographic security noticed that aging, shifts in ethnic distribution and migrations from rural to urban areas influence political security. Voter turnout and orientation is partially influenced by the age composition of the population (Herd and Sergsyan 2007: 55). Shifts in the ethnic structure, prompted either by natural movement or migration, also influence the political preferences of the population in a particular area, and in the case of inter-ethnic security dilemmas or conflicts may lead to radicalisation of political views and the articulation of such views through election results.

The economic component of security is also dependent on the structure of the population. The level of socio-economic development of a particular region is a true reflection and direct indicator of the demographic processes that are the demographic status of that particular region (Lajić 2010: 17).

The composition of the population is a determining development factor. In all types of society the population enters the economic process in a double role, as a producer - determining the overall labour potential of a country and at the same time as a consumer - determining the demographic dimensions of the domestic market and important characteristics of overall, and especially personal consumption (Wertheimer-Baletić 1999: 4).

Leahy and Peoples (2008), have underlined the implications of population aging on the economic potential of society by stating that: 
"As populations progress through the demographic transition, an opportunity for economic growth, known as the 'demographic dividend' arises. And, once death rates and birth rates decline due to investment in health, working-age adults make up the greatest share of population for a few decades and there are relatively small groups of dependent children and other adults. The lower dependency ratio can lead to higher savings and wages, greater per-capita spending on health and education at both household and governmental level, and increased participation of women in the labour force. These factors help boost national economies... The timeframe for countries to take advantage of this demographic window of opportunity is relatively narrow, often 40 to 60 years, lasting only until the median age of the population increases and dependency ratios rise again with the higher proportion of older adults (Leahy and Peoples 2008: 43-44).

Another consequence of population aging is the additional burden for pension, health and social funds. This situation, especially in the case of a society underdeveloped in human capital and technology, reduces society's productivity and prompts negative impacts on the economy.

In demographic-economic relations, there is distinct negative correlation at the global level. Developing countries with the strongest population pressures and the highest rates of population growth, yet economically challenged, are characterised by low domestic product, both aggregate and per capita (Wertheimer-Baletić 1999: 103). In contrast there are developed countries with very low rates of population growth, but high domestic aggregate and per capita product.

Finally there is a third paradigm defined by Nichiporuk taking into account the human capital of population and national power. This view holds that "the quality and skill level of a labour force is the most important demographic variable to overall national power..." (Nichiporuk 2000: 8).

This is particularly reflected in the economic component of security in states whose economies are based on the technological potential of skills existing in the workforce which is in clear correlation with productivity and therefore with economic growth. 
A distinct demographic factor with an impact on all aspects of security are migrations. What appears to matter in the case of potential conflicts are those cases wherein migration leads to clashes of national identity (Teitelbaum and Winters 1998: 197). This is when one distinct ethnic group migrates into an area that is considered the homeland of another ethnic group and challenges the dominance of the latter, here conflict is likely to arise (Goldstone 2002: 14).

Graham (2000) concludes that large immigration waves can harm the political, cultural, societal, economic, environmental and security homogeneity of states that are flooded with such migrants. Graham adds that, viewed from a conventional security viewpoint, population movements would only be perceived as a threat if the influx was an invading army or secondarily, a large number of refugees. ${ }^{7}$ This is thus not only about the physical security of people, but the so-called "ontological security". 8

According to Leuprecht (2010), migratory influx in the case of poor management by government institutions, leads to the so-called security dilemma ${ }^{9}$ in a domicile population, or in the case of demographic trends, a demographic security dilemma. This is a situation of mutual fear which encourages a chain of self-protective aimed actions and reactions between the domicile population and the newcomers, which may ultimately lead to a threat to national security, and even conflict. ${ }^{10}$

A percentage of foreigners amounting to $10 \%$ are enough to create tension among various ethnic groups (Soffer 2008: 16). Finally, a rise in legal or illegal immigration may eventually lead to xenophobic extremism.

7 Cited by Soffer, A., 2008. The Connection between Demography and National and International Security - The Case of the E.U. National Security and the Future, 1-2 (9) 2008. p. 10.

8 Leuprecht (2010) states that security is ontological security writ large, that is, the security of self, of individual and group identity and the environment (s) necessary to sustain that identity. The presumption is that ontological security is no less important to states, groups and individuals than physical security (Leuprecht 2010: 61).

9 The concept of security dilemma is primarily employed in the neorealist branch of international relations theory and emphasises the anarchic environment in which states exist. The concept of the security dilemma is based on the presumption that upgrading of a country's defense capabilities fosters a sense of threat in other countries and stimulates them to strengthen their own defence potential. In this way, the countries involved enter a continuous chain of actions and reactions that can lead to conflict. For more on the security dilemma, see Snow (2007: 166). 
Bearing in mind the power transition theory," such changes may on a regional or even municipal level lead to situations where a minority becomes the threat to the majority. In such situations, the struggle for the preservation of power by the majority and the demand for a redistribution of power from the growing minority may cause crises, and threats to national security. These are exactly the situations the SEE region faced in the outbreak of crises and armed conflicts during the last decade of the 20th century.

Threats arising from the changed relationships between minority and majority communities are particularly evident in sparsely populated areas.

Defined aspects of demographic security are broad, and connected to a population's composition, dynamics and human capital potential. In this paper we address demographic security through the elements of composition and dynamics according to Cincotta who addresses demographic security through elements of:

- A population's size, age structure, geographic distribution, or ethnic composition

- Changes in these demographic conditions and interactions between them, including migration, population growth, shifts in the age structure, and changing location and proportion of ethnic and religious groups (Cincota 2004: 24).

The ethnic structure of the population, as a particularly important component of demographic security and security in the SEE region and the issues of human capital paradigm due to their complexity, requires a separate analysis and is not the subject of interest in this paper.

11 Power transition theory was developed by Organski. With this theory he provided the basis for understanding causes of conflict between states in situations where the parties find themselves in conditions of power parity. These are situations in which the growing power seeks for change in power relations, and the existing power tends to preserve its position (Organski 1968) and (Organski Abramo and Kugler 1981). 

Europe

Through analysis of the population development, age structure and the total fertility rates in ten selected SEE countries we will identify specific demographic developments in the region and theirimpacton the definition of demographic security. Taking into account different methodological approaches and the inconsistent temporal dynamics of the censuses in the selected countries, as well as the reconfiguration of states at a given time period, the data from the World Bank will be used. The World Banks data on particular important demographic parameters allows the necessary level of methodological coherence and comparability.

The total population (Table 1) in the countries of this region declined in the period from 1980 to 2010, in all countries except Macedonia, Montenegro and Slovenia, which demonstrated continuous, yet modest growth in population. In Bulgaria, the total population has declined in the late 20th and early 21 st centuries. Between 1980 and 1990 the population was reduced by 143,246 inhabitants, and in the period between 2000 and 2010 the population was further reduced by as many as 635,883 inhabitants, which is a total of 7.534,289 inhabitants.

In Albania, the last increase in population was recorded between 1980 and 1990, from $2,734,776$ to $3,446,882$ inhabitants. This was followed by a period of population decline to 141,934 inhabitants by the year 2000 and by another 154,805 by the year 2010 , with 3,150,143 inhabitants living there.

In Bosnia and Herzegovina, between 1980 and 1990 the population increased from 4,099,903 to as many as 4,526,51 1 inhabitants. This period was followed by a significant drop of 692,147 people. By the year 2010 the trend was continuing and that very year only 3,845,929 inhabitants were recorded. In Bosnia and Herzegovina this trend was reinforced by significant losses during the war that was waged in the first half of the 1990s. A comparable demographic trend has also been noted in Croatia, which was also faced with the war in the first half of the 1990s. During the pre-war period between 1980 and 1990 the number of Croatian inhabitants had 
increased, from 4,580,000 to 4,780,000 inhabitants. In the year 2000, there was a population decline of 354,000 , this negative trend continuing until 2010 when Croatia recorded a population of only $4,417,800$.

On the other hand, Kosovo recorded a significant growth of population in the period 1980-1990, from 1,521,000 to 1,862,000 inhabitants. This was followed by a slight decrease of the population to 1,700,000 in 2000 and then a further increase until 2010, when 1,775,680 inhabitants lived in Kosovo.

In the year 1980 there were 579,880 inhabitants in Montenegro. By 1990 the population had increased by 35,513 to 614,601. By 2000 Montenegro had lost 3,405 inhabitants. This decline was followed by a period of slight increase after which, according to data for 2010, Montenegro has 620,078 inhabitants.

Romania, as the most populous country of the region, recorded 22,242,653 inhabitants in the year 1980. By 1990 the population of Romania had increased to $23,201,835$ inhabitants. Then the number of inhabitants started to decrease to $22,442,971$ in 2000 , and finally to $21,438,001$ inhabitants in 2010. During the observed period Romania has lost nearly $10 \%$ of its population.

Serbia has had continuous decline of population from 1990 onwards. Between 1990 and 2000 Serbia lost about 70,000 residents. In 1990 the population was 7,586,000 and in 2000 it was 7,516,346. Such a negative trend continued, and in the year 2010 a total of 7,291,436 inhabitants lived in Serbia.

During the period analysed Slovenia recorded a slight increase in population. In 1980 there were 1,901,315 and in $19901,998,161$ inhabitants. This was followed by a slight decline in the population until 2000 to $1,988,925$ inhabitants. Since then the demographic trend changed in Slovenia from negative to positive and as a result in 2010 there were 2,048,583 inhabitants.

Throughout the analysed period 1990-2010, excluding 1980 due to a lack of data for Serbia, the overall population of the region was decreasing. In 
the year 1990 these countries had a combined population of 58,743,989, and then until 2000 the population fell to 56,047,051. Between 1990 and 2010 the number of inhabitants decreased by 4,519,834, so the overall population of the analysed SEE countries was then $54,224,155$.

Table 1.Total population of SEE countries 1980 - 2010

\begin{tabular}{|c|c|c|c|c|}
\hline \multirow{2}{*}{} & 1980 & 1990 & 2000 & 2010 \\
\cline { 2 - 5 } & $2,734,776$ & $3,446,882$ & $3,304,948$ & $3,150,143$ \\
\hline Albania & $4,099,903$ & $4,526,511$ & $3,834,364$ & $3,845,929$ \\
\hline Bos \& Herz & $8,861,535$ & $8,718,289$ & $8,170,172$ & $7,534,289$ \\
\hline Bulgaria & $4,588,000$ & $4,780,000$ & $4,426,000$ & $4,417,800$ \\
\hline Croatia & $1,521,000$ & $1,862,000$ & $1,700,000$ & $1,775,680$ \\
\hline Kosovo & $1,895,727$ & $2,009,710$ & $2,052,129$ & $2,102,216$ \\
\hline Macedonia & 579,088 & 614,601 & 611,196 & 620,078 \\
\hline Montenegro & - & $23,201,835$ & $22,442,971$ & $21,438,001$ \\
\hline Romania & $22,242,653$ & $7,586,000$ & $7,516,346$ & $7,291,436$ \\
\hline Serbia & - & $1,998,161$ & $1,988,925$ & $2,048,583$ \\
\hline Slovenia & $1,901,315$ & &
\end{tabular}

Source: World Bank Available at: http://data.worldbank.org/indicator/SP.POP.TOTL.IN/countries (accessed 12 October 2013)

The negative demographic trend shown through the changes in total population of the SEE region is additionally burdened by indicators of the age structure (Table 2). The population's age structure is directly associated with natural demographic development, migrations and other events important for population development, thus pointing to the past as well as the future. The demographic literature provides different methodologies for population classification by age and sex structure. In this paper we opted for the classification developed by experts of the United Nations according to the proportion of the population aged "65 and over". This definition implies the dynamics and transformation of different types of population age structure related to the overall demographic development, by distinguishing three types of populations: a) the young population - with a proportion of elderly " 65 and over" $-4 \%$ or less, b) the adult population - with a proportion of elderly from $4 \%$ to $7 \%$, c) the old population - with a proportion of persons aged 65 years and over, more than $7 \%$ (UN, The Aging of Populations and its Economic and Social Implications, United Nations 1956). In the modern concepts of security, the age structure of the population, in correlation with the general potential of society in economic, political, social and military terms, determines the security status. 
Table 2.Population of SEE countries - Composition by age 1980-2010

\begin{tabular}{|c|c|c|c|c|c|c|c|c|c|c|c|c|}
\hline & \multicolumn{4}{|c|}{$\begin{array}{l}\text { Population } \\
\text { Composition by age\% }\end{array}$} & & & & & & & & \\
\hline & \multicolumn{4}{|c|}{$0-14$} & \multicolumn{4}{|c|}{$15-64$} & \multicolumn{4}{|c|}{$65<$} \\
\hline & 1980 & 1990 & 2000 & 2010 & 1980 & 1990 & 2000 & 2010 & 1980 & 1990 & 2000 & 2010 \\
\hline Albania & 38 & 34 & 30 & 23 & 57 & 61 & 63 & 67 & 5 & 5 & 7 & 10 \\
\hline Bos \& Herz & 28 & 24 & 20 & 17 & 66 & 70 & 69 & 68 & 6 & 6 & 11 & 15 \\
\hline Bulgaria & 22 & 20 & 16 & 13 & 66 & 67 & 68 & 68 & 12 & 13 & 17 & 18 \\
\hline Croatia & 22 & 20 & 17 & 15 & 68 & 69 & 67 & 67 & 11 & 12 & 16 & 18 \\
\hline Kosovo & - & - & - & 27 & - & - & - & 66 & - & - & - & 7 \\
\hline Macedonia & 29 & 26 & 22 & 17 & 64 & 66 & 68 & 71 & 7 & 7 & 10 & 12 \\
\hline Montenegro & 28 & 26 & 21 & 19 & 64 & 66 & 67 & 68 & 8 & 8 & 11 & 12 \\
\hline Romania & 28 & 24 & 19 & 15 & 62 & 66 & 68 & 70 & 10 & 11 & 13 & 15 \\
\hline Serbia & - & 24 & 20 & 17 & - & 66 & 67 & 69 & - & 9 & 13 & 14 \\
\hline Slovenia & 23 & 21 & 16 & 14 & 65 & 68 & 70 & 69 & 11 & 11 & 14 & 17 \\
\hline
\end{tabular}

Source: World Bank Available at: http://data.worldbank.org/indicator/SP.POP.TOTL.IN/countries (accessed 12 October 2013).

The age structure of the countries analysed (Table 2) clearly indicates that the population in as many as six countries: Bulgaria, Croatia, Montenegro, Romania, Serbia and Slovenia, during the entire period from 1980 to the year 2010, had the characteristics of an old population. Bosnia and Herzegovina and Macedonia showed the characteristics of a mature population in 1980 and in 1990. During the period between 2000 and 2010, as in other countries in the region, they developed characteristics that indicated an old population. In the case of Albania, it was only in the year 2010 that the population age structure change from mature to old became visible, which means a ten year delay in comparison with the trends in other countries of the region. It is interesting to note the same trend in Kosovo, but with a ten year delay compared to Albania. Kosovo's age structure thus had the characteristics of a mature population, with people over 65 years accounting for between 4 and 7 percent of the population. It should be noted that in 1980 and 1990 Kosovo was part of Serbia and for that period there is no valid demographic data. 
Table 3. Population of SEE countries - Total fertility rate 1980-2010

\begin{tabular}{|c|c|c|c|c|}
\hline & \multicolumn{5}{|c|}{} & 2000 & 2010 \\
\cline { 2 - 5 } & 1980 & 1990 & & 1.7 \\
\hline Albania & & & 2.4 & 1.2 \\
\hline Bos \& Herz & 2.7 & 3.0 & 1.4 & 1.5 \\
\hline Bulgaria & 2.1 & 1.7 & 1.3 & 1.5 \\
\hline Croatia & 2.1 & 1.8 & 1.4 & 2.3 \\
\hline Kosovo & $4.6^{*}$ & 1.6 & 3.0 & 1.5 \\
\hline Macedonia & 2.6 & 2.2 & 1.7 & 1.7 \\
\hline Montenegro & 2.3 & 1.9 & 1.8 & 1.3 \\
\hline Romania & 2.4 & 1.8 & 1.3 & 1.4 \\
\hline Serbia & $2.1^{*}$ & $1.8^{* *}$ & 1.5 & 1.5 \\
\hline Slovenia & 2.0 & 1.5 & 1.3 & \\
\hline
\end{tabular}

$* 1981, * * 1991$

Source: World Bank Available at: http://data.worldbank.org/indicator/SP.DYN.TFRT.IN/countries (accessed 12 October 2013).

Total fertility rate represents the number of children that would be born to a woman if she were to live to the end of her childbearing years and bear children in accordance with current age-specific fertility rates. Total fertility rate is the most dynamic and complex component in the natural change of population, which ultimately determines the future of a society and the range of structures and substructures of the population.

Among the many factors determining the level of fertility in a population, there are three interrelated groups: 1. biological factors, 2. economic and social factors and 3. psychological factors (Wertheimer-Baletić 1999). There is a consensus among scholars today, that the birth rate in modern societies is a component of the natural change of population, which is primarily affected by economic, social, cultural, and psychological factors. Demographers distinguish it as the most important determinant of the second demographic transition, pointing out that in most developed countries, fertility rates are not high enough to ensure a simple reproduction of the population. This trend is obvious in most SEE countries (Table 3) where the fertility rate in the period from 1980 to 2010 was continually declining. The fertility rates of all observed countries, with the exception of Kosovo, were below the replacement rate. The fertility rate in Kosovo decreased from 4.6 years in 1980 to 2.3 in 2010, but is still the highest in the region, and shows the characteristics of a country with expanding reproduction. Albania demonstrated features of expanding reproduction from 1980 to 2000 , but 
in 2010 the fertility rate dropped to just 1.7, which means that there is not even simple reproduction. As with the age structure of the population of Kosovo there is a ten year delay in fertility rate trends compared to Albania, so we can expect that within the next decade the fertility rate of Kosovo will converge with the demographic characteristics of neighbouring countries.

Macedonia last recorded a replacement fertility rate of 2.2 in the year 1990; Bosnia and Herzegovina, Bulgaria, Greece, Montenegro, Romania and Serbia even earlier, in 1980. In the same year Croatia and Slovenia had a fertility rate of 2.0 which until 2010 dropped to only 1.5, way below the level of simple reproduction.

Based on that analysis of demographic parameters, we can conclude that in Albania, Bosnia and Herzegovina, Bulgaria, Croatia, Kosovo, Macedonia, Montenegro, Romania, Serbia and Slovenia demographic development demonstrates negative characteristics or characteristics of stagnation. These countries are thus approaching demographic trends that characterise the developed countries of Europe. It is interesting to emphasise the ten-year lag of Albania compared to most countries in the region, and then the same lag from Kosovo to Albania. This indicates that in these countries the effect of the second demographic transition process, in which the natural components are primarily affected by socio-cultural and psychological factors, started somewhat later than in other SEE countries.

The delayed or negative demographic development of the SEE countries is reflected in all three analysed components: reduction or stagnation of the total population, the process of population aging and negative indicators of population reproduction. According to data from 2010, only Kosovo, with a total fertility rate of 2.3 percent, has fertility rate over the replacement rate, while the other nine countries are below the 2.1 percent which allows natural replacement of the population. We must point out that although all these changes are gradual, their effects are long-term, and reflected in all areas of the population as well as the overall forthcoming life of the population and society. We also agree with Nejašmić (2002) when he states that "after the tumultuous changes in the 1990s, there was a strong natural depopulation, that is of? decreasing reproduction of the population; there was a demographic collapse!" (Nejašmić 2002: 720). 


\section{( Migrations - impact on the demography of SEE}

countries

In addition to the described natural population movement in the SEE region, the mechanical movement of population - migration - also has a significant impact.

Migration is the most dynamic component of population movement and represents the most complex research subject in terms of content and methodology.

The mobile part of the population (migration contingent) mechanically changes its geographical location and in proportion to its demographic volume "moves" all its human potential (biological, structural, cultural, etc.) to the region of immigration (Lajić 2010: 15). Once arrived in a new locality migrants may retain their attitudes, religion, language, culture and genetic identity for a longer or shorter period (Roberts 1988: 46).

International migration has more than doubled in the past 50 years. There are some 232 million international migrants today. In 2000-2009, the EU population gained almost 15 million people through net migration. This number is higher than the total for the previous four decades, making the European Union a more important migration destination than the United States during this period (Sobotka 2009: 217). The EU also became an important immigrant continent.

In SEE countries migration is perceived as an important factor of demographic change and key driver of population development. Some authors characterise this field as a "new regional migration pole" (Garson et al. 1997), and it is generally understood that population shaped by migration trends is quantitatively and qualitatively highly heterogeneous.

A particular challenge to migration research, as well as the complexity of the issue, is the lack of good quality data and terminology, as well as the differences in definitions and sources used in various countries and in the coverage of the statistics. All this makes comparative research on migration 
in Europe more difficult (Kupiszewska et al. 2010), especially in countries whose migration trends are of interest for the purpose of this paper.

Several political factors have significantly determined the migration flows in SEE countries in the late 20th and the first decade of the 21 st century: the end of the socialist system in Europe, the breakup of the Socialist Federal Republic of Yugoslavia as a socialist federation, and the creation of new states. While in Bulgaria, Romania and Albania, this occurred without changes to the integrity of the state, the breakup of the Socialist Federal Republic of Yugoslavia was followed by wars that brought dramatic changes. Wars, as stated by Šterc and Komušanac, are "the greatest social and demographic destruction and direct post-war demographic movement to a significant degree" (Šterc and Komušanac 2011 : 696).

Studies have shown that the total demographic losses, (direct demographic losses, losses in the birth rate and migration losses) in Bosnia and Herzegovina in the period from 1992 to1995 amounted to approximately $1,135,966$ residents, which is $25.95 \%$ of the population in 1991, or around a quarter of the pre-war population (Tanović et al. 2014, 245). According to the results of research conducted by Živić and Pokos $(2004,727)$, during the Homeland War in Croatia the total demographic war losses in the period 1991-2001 amounted to 450,276 inhabitants. In the structure of these losses, migration losses comprised $92.94 \%$, war mortality $4.93 \%$, and natality losses $2.13 \%$. If the mentioned demographic war losses are reduced by the contingent of immigrants into Croatia between 1991 and 2001 (232,966 persons), we have a net balance of demographic losses comprising 217,310 persons. The war in Kosovo 1998/99 also triggered waves of internal and external migration; the overall number of persons who migrated was $1,480,000$ or $71 \%$ of the total population. According to surveys, approximately 1,150,000 persons or $55 \%$ of the population temporarily left Kosovo during the conflict, and some 555,000 persons or $27 \%$ of the Kosovo population stayed in refugee centres on at least one occasion (Bergovignan and Blayo 2011).

Migration from the Western Balkans to the EU is not new, but the volume of migration from Kosovo in early February 2015 surprised many. There is no precise information on the number of Albanians who have left Kosovo, but estimates indicate that around 100,000 have left since August 2014. 
Another consequence of these wars are the great humanitarian crises, followed by movements of refugees and displaced persons from Croatia and Bosnia to FR Yugoslavia and from Bosnia to Croatia. In the early 1990s the number of immigrants from the Balkans residing in a Western Europe country was especially high in Germany, Austria and Switzerland (Bonifazi and Mamolo 2004: 524).

The change of the political system and disappearance of restrictive state control over migration triggered the departure of many people, especially inhabitants of Albania and Romania. Different sources suggest that around one million Albanians have moved temporarily or permanently across its borders since the beginning of the transition period (INSTAT, 2004; Labour Market Review of Albania, 2006). In the decade from 1990 to 2000 , Albania lost more than $21 \%$ of its population. Albania is still the country with the strongest negative migratory growth (Avdeev 2011). Migrations are the phenomenon at the heart of economic, social, and cultural change in Albania over recent decades (King, 2005: 133). Romania has been the largest country of departure with an average of more than 200,000 people per year. In Bulgaria, the liberalisation of passport restrictions in 1990 created a framework for emigration. The decisive factors for asylum migration, however, mostly to Germany, were political instability and a desperate economic situation at the beginning of the 1990s (Bobeva 1996: 37).

During the 1990s and 2000s Montenegrins emigrated to Western Europe as well as to some overseas countries, however, during this period, immigration to Montenegro was also recorded, albeit lower than the emigration.

Due to the problems with the availability and quality of data, it is not easy to give even a rough estimate of the overall scale of immigration to, and emigration from Serbia, but, traditionally the Republic of Serbia has been a country of economic emigration which has nevertheless experienced several inflows of immigrants consisting mainly of ethnic Serbs from the territory of the former Yugoslavia (Nikitović 2014).

External migration in the Republic of Macedonia has over a long period of time shown a dominant tendency for emigration to Western European 
and overseas countries. Emigration stands out as one of the societal and economic processes which have marked the 20th and has continued at an unabated pace well into the first decade of the 21 st century. Recent migration flows from the Republic of Macedonia abroad have over the past four decades exhibited a tendency of continuous increase (Bonifazi and Mamolo 2004: 523).

Migration trends in Slovenia reflect an entirely different situation. Slovenia expects to remain in a pattern of growth, entirely based on immigration. Slovenia is the only country where natural and migratory dynamics are both positive and mutually reinforcing. Most immigrants are from exYugoslavia, but Slovenia is also now beginning to attract immigration from countries to the east (Sobotka 2009: 231).

An important stimulus to migration is the accession of selected SEE countries into the European Union in 2004 (Slovenia), 2007 (Bulgaria and Romania) and 2013 (Croatia) which, in addition to the great economic crisis and recession that began in 2008, prompted the free movement of persons within EU member-states. There is a gradient of material welfare in Europe from the southeast and east, to northwest and west, and people migrate from the marginal states to the comparatively wealthier ones (Reiterer 2010: 124) creating a new migration landscape in the EU. This changes the size, composition and destination of migration. Whereas Germany and Austria were the main destinations of east - west migration in the early 1990s, Italy, Spain, Portugal, Greece, Britain and Ireland, all traditional emigration countries, became major destinations at the beginning of the 21 st century.

The birth rates of the SEE countries are low and migration brings new political, cultural challenges and addressing new questions for scientists, policymakers and public opinion.

The data in Table 4 (showing migration flows in the period 2010-2015) shows that the defined trends are continuous, and that all observed states except Slovenia, (there is no data available for Kosovo), register a negative migration balance. 
Table 4. SEE Migrations, Flows 2010-2015, Net migration

\begin{tabular}{|c|c|c|}
\hline & \multicolumn{2}{|c|}{} \\
\cline { 2 - 3 } & Number (thousands) & Rate per 1.000 \\
\hline Albania & -7.3 & -2.3 \\
\hline Bos \& Herz & -0.2 & -0.0 \\
\hline Bulgaria & -9.8 & -1.3 \\
\hline Croatia & -5.1 & -1.2 \\
\hline Kosovo* & & -0.4 \\
\hline Macedonia & -0.8 & -0.8 \\
\hline Montenegro & -0.5 & -0.4 \\
\hline Romania & -9.1 & -1.8 \\
\hline Serbia & -16.6 & 1.7 \\
\hline Slovenia & 3.4 & \\
\hline
\end{tabular}

* Data not available

Source: INED Available at: http://www.ined.fr/en/everything_about_population/graphs-maps/internationalmigration/ (accessed 17 May 2015).

\section{Impact of demographic trends on demographic security}

The analysis of data on the defined demographic features of SEE countries indicates that overall population development in the observed SEE countries is shaped under the influence of natural and mechanical (migration) factors.

The demographic legacy from the pre-transition, socialist period in most of these countries was unfavourable. ${ }^{12}$ The transition period that followed was marked by a complex and difficult social and economic transformation and accompanied by high unemployment rates.

Transition processes in the 1990s, which in some of the observed countries (Romania, Bulgaria, and Albania) were followed by the opening of the borders which made it possible for the population to go abroad, coupled

12 In the analysis of demographic development of the European post-communist countries, which also includes the ten countries subject to this analysis, Nejašmić (2002) concludes that "the demographic legacy from the socialist period in most of the analyzed countries had been unfavourable. Thus, most countries entered a dramatic period of political change and overall social and economic transition with weakened population potential and unfavourable tendencies of demographic development" (Nejašmić 2002: 720). 
with the economic crisis and high unemployment rate in all analysed countries, prompted negative demographic trends, in regard to both natural and mechanical factors.

In addition to the transition processes, Bosnia and Herzegovina, Croatia, Kosovo, Macedonia and Serbia were caught up in armed conflict and wars that further incited significant migration flows which had exceptionally negative consequences on population development.

The economic crisis and high unemployment rates, particularly among young adults, continue to encourage emigration and a negative migration balance. This also discourages natural reproduction of the population whether through the emigration of youth or a reluctance to have children in the given circumstances.

The consequence is visible through the basic demographic indicators analysed. The region as a whole, as well as most of the analysed states are characterised by a continuous decrease or stagnation of the total population for natural and mechanical reasons. The age structure of the population, with the exception of Kosovo, is unfavourable and characterised by an old or mature population, with an aging tendency.

The analysis of the combined population shows that only Macedonia, Montenegro and Slovenia record a slight increase. The other countries are characterised by a decline, and it is noticeable that in all countries, with the exception of Bulgaria, the population peak was reached in 1990, right before the democratic and market transition began. This is also the time when the fertility rate fell significantly, under the replacement level in all observed countries, with the exception of Albania, Kosovo and Macedonia. This was therefore the demographic turning point, and there was a subsequent strong effect from the negative natural and mechanical factors on the population movement. The consequence was inevitable and has led to the accelerated population aging; Kosovo is the only country that deviates from the trend to a significant degree.

Total fertility rate data shows that a naturally driven change to the trends and demographic characteristics of the SEE countries cannot be expected. Countries in the region, again with the exception of Kosovo, are 
characterised by extremely low fertility rates which are significantly below the replacement rate. Kosovo is ten years behind Albania with regard to fertility rate decline; but it can be expected that the fertility rate will decline until it is under the replacement level in Kosovo as well. Given Kosovo's very young age structure, however, this will not automatically result in population decline. Kosovo is a generation from achieving population stabilisation due to the phenomenon of population momentum.

The slow or negative demographic development of the SEE is therefore evident in all three analysed components; population trends, age structure and the reproductive potential of the population - fertility rate.

Migration, with its influence on standard demographic development, also impacts demographic trends in SEE; and all analysed countries, with the exception of Slovenia and Macedonia, have a negative impact on the demographic balance. A particularly strong negative impact on the population growth rate was recorded in Albania, Bosnia and Herzegovina, Kosovo and Romania.

The negative demographic development of the population can only be replaced with an influx of people through migration. SEE countries, so far, haven't been an attractive target destination of international migrants.

Such a demographic situation, independently or in correlation with other security components may have negative consequences on economic, political and security-related aspects of the SEE countries analysed.

In the post-war era, employment growth has been a major, and sometimes the dominant, contributor to economic growth in developed countries (Jackson and Howe 2008: 58).

Most SEE countries, as shown by analysis of demographic trends, have passed the period of "demographic dividend", and in some the consequences of wars and emigration have had further impact on the sudden negative changes in the population, preventing the "demographic dividend" from being economically expressed and capitalised. Albania and Kosovo haven' $t$ passed the period of "demographic dividend" but as a result of the significant emigration of young people in particular, they don't benefit from it. 
Due to the economic crisis and significantly high unemployment rate, the negative consequences of this situation have not become entirely visible. The relationship between the dependent and working population will determine both the outcome of the crisis and economic development in the long term.

In addition to the aging process in most SEE countries, there is also population stagnation and decline which has a negative impact on demographic dimensions of the internal market. Only in the case of Kosovo might more significant growth be expected, should the outflow of youth be stopped.

In addition to the increase in the negative correlation between the dependent and working population, "... aging is likely to place substantial demands on governmental spending for retirement and health care and their related costs"(Haas 2007: 116-7). Such budget-related effects of society aging leave fewer funds available for other social groups and development.

As societies age, they must transfer a rising share of income from working adults to non-working elders, whether through families, financial markets, or government budgets (Jackson and Howe 2008: 50-52).

The elderly will not be a dominant economic force - due in large part to the huge share of national resources that will be steered toward them through public budgets (Jackson and Howe 2008: 104).

The transfer of funds from one age group to another raises the issue of intergenerational solidarity. Possible reactions of the employed, especially the younger employed, to additional financial and tax burdens is to have fewer children, to emigrate and seek more favourable work conditions ${ }^{13}$; to develop a more negative attitude towards the elderly; or to strengthen political competition with the elderly (Jackson, Howe 2008). These are all elements that could negatively affect a country's demographic security.

13 It should be noted that unemployment is the main trigger of migration in SEE, but it is precisely under such conditions that a financial burden could be an additional reason for emigration. In the case of Croatia, even though it is not possible to accurately estimate potential migration contingents, concern about the opening of labour markets of EU member countries to Croatian citizens is indicative in this context. It is estimated that over 100,000 individuals, primarily young adults, might leave Croatia. 
In societies marked by population aging the elderly are becoming a dominant political subject. In accordance with an increasing share of the elderly in the total population, their share in the electorate of a country is increasing too, thus increasing the possibility of their influencing the election of political representatives. "Since the elderly vote with greater frequency than younger adults, their electoral clout will be further magnified" (Jackson and Howe 2008: 50-52).

The retired segment of the population tends to formalise its political participation. In SEE countries, we see a number of pensioner political parties and their participation in government. Their growing political influence means a growing influence on budget appropriation. In such a situation, decision makers face a dilemma in acting under the circumstances of the growing influence of the elderly on the one hand, and dominant dependence on the work potential of the young on the other.

"With aging populations, governments will be under pressure to pay for massive new expenditures for the elderly (and most likely in the context of slowing economic growth) that all other discretionary spending will likely be affected" (Haas 2007: 127). This means that defence and security expenditure within the framework of discretionary spending will be under more intense reduction pressure. Given the new security paradigm which sets new challenges for security systems in facing threats in terms of necessary human, technical and financial resources, this may lead to a weakening of defence potential and security in general.

A positive consequence of the aging population is a stronger desire to avoid conflict in international relations, which consequently reduces the possibility of international conflict. Readiness for international engagement in general is being reduced in parallel with the aging population ${ }^{14}$, however, which reduces the potential for a cooperative approach in international crises management. Given the demographic trends, this "conflict provoking fatigue" can be expected in SEE as well.

Still, one has to bear in mind that demographic changes affect not only the possibility of interstate conflicts but "...by altering the domestic politics of a given state it becomes a security problem for its neighbours" 
(Nichiporuk 2000: 29). This threat is a possibility in SEE, chiefly because of the weak institutional structure and non-consolidated interethnic relationships in Bosnia and Herzegovina and Macedonia. Consolidation of interethnic relationships is determined, among other things, by the different demographic dynamics of ethnic groups of Albanians and Macedonians in Macedonia, and Bosnians, Croats and Serbs in Bosnia and Herzegovina. We will not go any further because, as stated in the introduction, the ethnic issues in the region, as a particularly demanding component of SEE demographic security, are not the subject of this paper and require a separate and deeper analysis.

SEE is a region located between demographically propulsive MENA (Middle East and North Africa) and Central Asia regions and Western Europe as desired destination for most migrants. Even though the region is a transit area, given the distinct demographic imbalance and the increasing phenomenon of migrant transit, most often illegal, the potential for retaining a certain number of migrants will grow, as will creation of new ethnic communities with associated security challenges ${ }^{15}$.

The sparse and uneven population of the region, even in the case of limited migration, can lead to significant consequences for security. A migration influx, into some of those sparsely populated areas with its request for redefinition of the relationships of different communities as described in power transition theory, could pose security threats through the demographic security dilemma.

\section{Conclusion}

SEE has entered a complex demographic period that has not been observed in previous periods in terms of its features and negative trends

15 The processes could be prompted in the countries of the region that are members of the EU if the European Commission persists in proposals to disperse illegal migrants and refugees across member states. European Commission - Fact Sheet, First measures under the European Agenda on Migration: Questions and Answers. Brussels, 27 May 2015. Available at http://europa.eu/rapid/press-release_MEMO-15-5038_en.htm site consulted on 18.6.2015. It is precisely such a dictated transfer of refugees that could lead to the creation of the so-called host communities that subsequently serve as a factor of attraction and reception of other migrants from the same area or belong to the same ethnic group. 
- the overall population decline, population aging, low fertility rate and significant migration outflow. The analysed demographic data for ten SEE states indicates the unfavourable trends for their economic, political and security contexts.

A large and growing share of the economically dependent population, in comparison to the active, working population, hinders the dynamic economic development of society. This period is particularly important in the context of SEE countries regarding the significant economic lag of those states behind the levels of economic development recorded in the EU.

The countries of the region could face, or are already facing, a particularly challenging situation, which Haas describes as "...disadvantage of growing old before growing rich...", which will "...greatly handicap these states' ability to pay for elderly care costs" (Haas 2007: 146).

The development of society, as is shown in the analysis, depends on the demographic structure of the population and the demographic trends that characterise a society. Demographic development with negative characteristics and the characteristics of stagnation determines the overall potential of society not only for economic development but also for social development.

Future demographic processes, which have arisen from the current situation, and which are in the long-term formed on the basis of demographic inertia, will effect the social structure and social relationships in a more powerful way (Nejašmić 2002: 720). "An exceptionally high natural rate of decline, significant population aging and the appearance of a negative external migration balance confirms the conditions for a new period of very slow population substitution. This is further fuelled by the economic recession, high unemployment rate, unstable society and all systems within the society [...]" (Šterc and Komušanac 2011: 703).

The dominant trends ofstagnation ordecline of population are the processes with a long-term negative impact on a number of other demographic structures, as well as the general demographic development of society. Fast changing trends are not possible. Since the negative trends have been developing over a long period of time, a reverse process - even in 
favourable social, economic and political conditions - would take a long time. Significant changes in the determined trend cannot be expected in the foreseeable future.

Following the analysis of the components of demographic security it can be concluded that the countries analysed in the region of SEE demographic security have the potential to adversely affect security and the adverse effect will continue. In this respect, the question of demographic security is a strategic question of future national power and security in the SEE countries.

Jackson and Howe warn that "... demographic aging will affect more than the size and structure of the population and economy. The burgeoning proportion of elderly in the population, the smaller size of families, and growing ethnic diversity promise to recast every facet of society from the popular culture to politics. More fundamentally, they could shift society's overall direction and political agenda" (Jackson and Howe 2008: 95).

In the given circumstances, strategic planning for population development is particularly important, due to the needs of economic development but also the development of society in general.

Special attention should be paid to demographic policies that will slow population decline and aging, ensure migration flow management and encourage investments in human capital; economic policies that respond to the changes in the labour contingent and internal market and possible negative effects conditioned by demographic changes; and security policies that will harmonise the structure and goals of the security system with new demographic realities. 


\section{B Bibliography}

Bergovignan, C., and Blayo, C., 2011. Raseljavanje stanovništva Kosova tokom sukoba iz 1999. godine, Migracije, krize i ratni sukobi na Balkanu s kraja 20. Veka. Ur.: Goran Penev, Društvo demografa Srbije, DémoBalk, Beograd. 101-121.

Bobeva, D., 1996. Bulgaria. In: T. Frejka (ed.), International Migration in Central and Eastern Europe and the Commonwealth of Independent States, 37-47. New York and Geneva: United Nations.

Bonifazi, C., and Mamolo, M., 2004. Past and current trends of Balkan migrations, Espace populations societes 2004/3, Les populations des Balkans, http://eps.revues.org/356, Accessed on: August 3, 2015.

Buzan, B., Waever, O. and de Wilde, J., 1998. Security: A New Framework for Analysis. Boulder CO:LyneRiener.

Cincotta, R.P., 2004. Demographic Security Comes of Age, Environmental Change and Security Programme Report, Issue 10: 24-29.

Goldstone, J., 2002. Population and Security: How Demographic Change Can Lead to Violent Conflict. Journal of International Affairs, 56(1): 3-22.

Goldstone, J., 2009. Demography and Security: Security Implications of Global Population Changes, 2007-2050. Research Paper No. 200907, George Manson University.

Grizold, A., 1998. Međunarodna sigurnost: Teorijsko-institucionalni okvir. Zagreb: Fakultet političkih znanosti.

Haas, M. L., 2007. A Geriatric Peace? The Future of U.S. Power in a World of Aging Populations, International Security, 32(1): 112-147

Herd, G.P., Sargsyan, G., 2007. Debating Russian Demographic Security: Current Trends and Future Trajectories, Security Index No. 2 (82), 13:51-67.

INSTAT. 2004., People and Work in Albania. Tirana. INSTAT.

Jackson, R. and Howe, N., 2008. The Graying of the Great Powers: Demography and Geopolitics in the 21st Century, Washington D.C: 
Center for Strategic and International Studies.

King, R. 2005., Albania as a Laboratory for the Study of Migration and Development. Journal of Southern Europe and the Balkans. 7(2): 133-155.

Kupiszewska, D., Kupiszewski, M., Martí, M. and Ródenas, C., 2010: Promoting Comparative Quantitative Project funded by the Research in the Field of Migration European Commission, DG Research and Integration in Europe Sixth Framework Programme, Priority 8, (PROMINSTAT).

Lajić, I., ur. 2010. Migracije i regionalni razvoj Hrvatske. Zagreb: Institut za migracije i narodnosti.

Leuprecht, C., 2010. The Demographic Security Dilemma. Yale Journal of International Affairs, 5(2): 60-74.

Leahy, E. and Peoples, S., 2008. Population and Security: Risks from Growth, Migration, and Environmental Stress. World Watch, Sep/Oct: 40-45.

Luciani, G., 1989. The Economic Content of Security. Journal of Public Policy, 8(2): 151-173.

Morgenthau, H., 1967. Politics Among Nations, New York: Alfred A. Knopf.

Nejašmić, I., 2002. Demografski razvoj U europskim postsocijalističkim zemljama (1990.-1999.). Društvena istraživanja, br. 4-5 (60-61): 701-723.

Nichiporuk, B., 2000. The Security Dynamics of Demographic Factors. Santa Monica: Rand.

Nikitović, V., 2014. Migration Transition in Serbia: A Realistic Future or Just a Hypothetical Model? European Population Conference 2014, Budapest, Hungary, 25-28 June.

Organski Abramo, F.K., 1968. World Politics. New York: Alfred A. Knopf.

Organski Abramo, F.K. and Kugler, J., 1981, The War Ledger. Chicago: University of Chicago Press.

Podolski, A., 1999. Political and Social Determinants of Legal Regime, Political Oversight and Tasks Performed by Special Services Democratic, Totalitarian, and Post-Totalitarian Perspective, NATO Research Fellowship 1997-1999 Project. 
Pokos, N. and Mišetić, R., 2009. Temeljni demografski pokazatelji hrvatskog pograničnog pojasa. In: Smerić, T. and Sabol, G.,ed. Sigurnost $i$ obrana Republike Hrvatske u euroatlantskom kontekstu, Zagreb: Institut društvenih znanosti Ivo Pilar.

Reiterer, A.F., 2010. Migration and the Demographic System in East Central Europe, The Whitehead Journal of Diplomacy and International Relations. www.journalofdiplomacy.orhttp://data.worldbank.org/ indicator/SM.POP.NETM

Roberts, D. F., 1988. Migration in the Recent Past: Societies with Records. In: Ed. C.G.N. Mascie-Taylor \& G.W. Lasker, Biological Aspects of Human Migration. New York: Cambridge University Press: 41-70.

Sobotka, T., 2009. Migration continent Europe, Vienna Yearbook of Population Research, 2009 special issue: 217-233 (DATA\&TRENDS).

Soffer, A., 2008. The Connection between Demography and National and International Security - The Case of the E.U. National Security and the Future, 1-2 (9): 9-23.

Šterc, S. and Komušanac, M., 2011. Neizvjesna demografska budućnost Hrvatske - izumiranje i supstitucija stanovništva ili populacijska revitalizacija...? Društvena istraživanja, 3 (117): 693-713.

Tanović Lukić, M., Pasalić, S., and Golijanin, J., 2014. Demographic development of Bosnia and Herzegovina from Ottoman period till 1991 and modern demographic problems. Procedia - Social and Behavioral Sciences 120: 238-247.

Teitelbaum, M. S. and Winters, J. A., 1998. Question of Numbers: High Migration, Low Fertility and the Politics of National Identity. New York: Hill \& Wang.

Van de Kaa, D.J., 1987. Europe's Second Demographic Transition. New York: Population Bulletin 42.

Vilijams, P. D., 2012. Uvod u studije bezbednosti. Beograd: Službeni glasnik i Univerzitet u Beogradu - Fakultet bezbednosti.

Wertheimer - Baletić, A., 1999. Stanovništvo i razvoj. Zagreb: Mate. 
Živić, D. and Pokos, N., 2004. Demografski gubitci tijekom Domovinskog rata kao odrednica depopulacije Hrvatske (1991. - 2001.) Društvena istraživanja, 13: 4-5 (72-73), 727-750.

Dario Malnar (malnar.zg@gmail.com) graduated law at the University of Zagreb, Faculty of Law. He holds MSC and PhD degree in political science from the University of Zagreb, Faculty of Political Science. During his professional career he worked in the embassies of the Republic of Croatia in Belgrade, Ljubljana and Pristina and has been professionally engaged on issues of national security. His research interests are foreign policy, international relations and security. He is author of one scientific book and (co-)author of ten scientific articles. He has participated with papers at national and international conferences. He holds a scientific title Research Associate in political science.

Ana Malnar (amalnar@imin.hr) worked at the Institute for Anthropological Research and nowis Research Associate at the Institute for Migration and Ethnic Studies in Zagreb. She graduated history at the Faculty of Humanities and Social Sciences, University of Zagreb. She holds MSc degree from the Faculty of Science, University of Zagreb and PhD degree from the Faculty of Humanities and Social Sciences, University of Zagreb. She teaches Anthropological Demography at the Faculty of Humanities and Social Sciences, University of Zagreb. Her research interests are anthropology, anthropological demography, migrations, and youth. She is/was participant in many international research projects and field researches in Europe and Africa which resulted with publishing in relevant scientific journals. She is member of Croatian Anthropological Society and European Anthropological Association. She is an active participant at international conferences. 